\title{
EFL Learners' Beliefs about Speaking English and Being a Good Speaker: A Metaphor Analysis
}

\author{
Ali Dincer \\ Department of English Language Teaching, Faculty of Education, Erzincan University, 24100, Erzincan, Turkey
}

Copyright $(2017$ by authors, all rights reserved. Authors agree that this article remains permanently open access under the terms of the Creative Commons Attribution License 4.0 International License

\begin{abstract}
This study aimed to investigate the beliefs of English as foreign language (EFL) learners about speaking in English and being a good speaker of English through metaphor analysis. A phenomenological approach was adopted and 60 EFL learners completed a questionnaire with demographic questions and two prompts focusing on the characteristics of a good English speaker (i.e., "Speaking English is like... because..." and "A good speaker of English is like... because...”). For the first prompt about speaking English, 46 valid metaphors were determined, which were categorized under five conceptual themes. For the second prompts about being a good speaker of English, 27 valid metaphors were given, with six conceptual categories identified. Findings showed that learners mostly perceived speaking as a skill requiring much effort and also giving pleasure. They described a good speaker of English as someone who is fluent at speaking, universal, disarming, wise, privileged and hardworking. The conceptual categories were also described with the speaking achievement and these categories were found to be connected to the degree of achievement. The findings gave insight into a better understanding of the speaking skill and what makes a good speaker of English for language educators.
\end{abstract}

Keywords EFL Learner, Metaphor, Language Learner Belief, Speaking

\section{Introduction}

"If a picture is worth 1,000 words, a metaphor is worth 1,000 pictures!" [1] p. 102

In this globalizing world, speaking English has become a priority for many people and receives more attention due to its importance in daily life [2, 3]. Unlike its priority and deserving attention, oral communication is less supported, with the speaking skill often regarded as being the least important in EFL classrooms. As there are few opportunities to practise English in realistic situations, it is much neglected in most EFL settings. As such, many EFL learners perceive an English course as just a curricular subject and 'something to dabble in'. Therefore, the speaking skill has become the main focus in recent years, with much research having been conducted into the nature of a better education and success in mastering oral proficiency. Although numerous studies have investigated speaking classrooms and put forward suggestions for the improvement of EFL learners' oral communication proficiency, many students have still defined themselves as incompetent and finding the speaking skill difficult to master $[4,5]$. This maybe because of the speaking skill itself, as it is the most complex and challenging skill to master [6, 7], while research has focused mostly on the linguistic aspects of language learning $[5,7]$.

Consequently, this study focused on EFL learners' beliefs in relation to understanding the nature of this skill, as well as providing some insight to educators on the effective assessment of classroom practices. In this process, metaphor, which turns an abstract concept into a more concrete one [8], was used as an analysis tool. Therefore, the study aimed to elicit EFL learners' beliefs and conceptualizations regarding the speaking and being a good speaker of English.

\section{Literature Review}

\subsection{Speaking English}

Today, the speaking skill is not just synonymous with knowing and using a language among language learners; it is, by far, the most demanding among four macro skills [9]. This is because of the role of English as a lingua franca in today's world and its crucial role in cases where the interactants do not know each other's languages [10].

Despite its importance in current life, many EFL learners are far from even starting basic communication in the target language, which in turn makes the teaching of speaking a central concern for educational policies in many EFL contexts that share similar characteristics [11-14]. Speaking, 
as the most difficult skill to master [6], is more than simply knowing the grammatical and semantic rules of a language [15]. It is also about the control of a highly diverse set of activities, which involves many distinct mental and physical skills [9]. In addition to its complexity, it is not particularly supported with real situations in language learning contexts [11]; rather, it is taught within the confines of a school class, which serves as the only setting for learners to practise English $[16,17]$. This issue makes it difficult for language learners to gain proficiency $[11,17]$. Furthermore, it is an anxiety-provoking skill, which hinders performance [18-20], as EFL learners become more concerned about their performance and believe they are not performing well enough [17].

Much practice is suggested as a panacea for lessening the effects of negative factors, with the time spent in speaking connected to a higher oral proficiency and motivation to speak. In other words, much exposure to speaking English means greater achievement and fewer problems in learning to speak [17, 21-23].

\subsection{Language Learners' Beliefs}

Investigating learners' beliefs is a means of understanding learners' expectations of, success in and satisfaction with a learning activity [24]. The beliefs considerably impact on both the progress and success of any learning activity, as well as being a direct influence on attitude and motivation [25-27]. There is currently a growing body of research investigating learners' beliefs in diverse education domains. This trend has also gained momentum in language learning, especially in recent decades [28].

In the second/foreign language (L2) research field, researchers have primarily concentrated on the learner aspect and generally studied beliefs about the experiences in language learning [19, 24, 26, 28-34]. Previous studies have shown that learners' beliefs constantly evolve in accordance with learners' previous experiences in the learning process [29, 33, 34]. As proposed by Hortwiz [29] and Mantle-Bromley [30], students' negative beliefs can inhibit their learning process and persistence in language learning. This issue can lead to some detrimental outcomes, such as the deployment of less efficient learning strategies or wasting time with traditional approaches, all of which may result in limited proficiency $[33,35]$. In addition to these aspects, some researchers have focused on learner perceptions, such as the role of EFL teachers [36] the role of English at an international level [37], while some focus on psychological factors, such as motivation and anxiety $[4$, 38].

Based on the learners' belief literature, it can be concluded that there is a consensus regarding its importance and positive contributions to more effective foreign language instruction. Therefore, more research addressing learners' beliefs in different aspects would be helpful in terms of facilitating language learning processes [39].

\subsection{Metaphor as a Research Tool in Language Education}

Metaphor is a pervasive concept in daily life. It is a kind of thinking process relating an abstract concept in terms of another one and turning abstract issues into more concrete ones [8]. It is not just a form of speech; it is also "more fundamentally a form of thought, having basic epistemological functions" [40] p. 4. Given that it is a way of gaining insight into individuals' way of thinking, it is accepted as a research tool in social sciences (for a review, see [41]).

Metaphor analysis has been extensively used in social scientific research, while a considerable amount of literature has been published in the educational research domain to date (e.g., [42-44]). It has also been used in order to explore learners' beliefs in L2 research in recent years (e.g., $[36,41,45,46])$. This issue may be because of the feature of metaphor in solidifying phenomena or an idea with the use of a better or already known image, as well as its contribution in diagnosing, treating and solving problems in the process of education [46].

In the L2 field, researchers have focused on language learners' beliefs about different educational phenomena, such as learning a foreign language [28], English teachers [36, 47]; L2 motivation [45], standard foreign language tests [46] and language teaching course books [41]. These studies have reported learners' metaphors and conceptual categories related to the above concepts. They have presented research-based implications for language educators and policymakers when designing effective instructional practices. All in all, they have provided evidence about the usefulness of metaphor analysis as a research tool, revealing underlying structures in less-known L2 concepts.

\subsection{Significance of the Study}

Exploring language learners' beliefs is still needed because it has the potential to offer language teachers important insights into understanding and refining language learning processes, as well as applying better teaching practices. Although there is a considerable amount of research regarding language learners' beliefs, speaking, as a particular language skill, has attracted far less attention among researchers $[48,49]$. Consequently, there is a limited body of research focusing on this skill (e.g., [5]). Further, the available literature on research into language learners' beliefs appears to be dominated by quantitative studies, based mostly on the Beliefs About Language Learning Inventory [24]. Given that only a few published qualitative analyses of the phenomenon exist, a qualitative study, which focuses on learners' beliefs about the often-neglected speaking skill in EFL contexts, may contribute to the scientific understanding of learners' beliefs about speaking English. 


\subsection{Aim of the Study}

The study aimed to reveal EFL learners' beliefs regarding English speaking and being a good speaker of English by using a metaphor analysis approach. The following research questions guided this study:

1. What are the metaphors that EFL learners have about speaking English and being a good speaker of English?

2. What are the conceptual categories of EFL learners' perceptions regarding speaking English and being a good speaker of English?

3. Are there any associations between conceptual categories and achievement in speaking?

\section{Methodology}

\subsection{Research Design}

This study adopted a phenomenological research design, which helps researchers understand a phenomenon from the viewpoints of the people who shared the experience of the phenomenon [50]. For a clear understanding of the speaking skill and in order to reveal learners beliefs, metaphor analysis as a qualitative research tool [51] was used in the study.

\subsection{Subjects}

The subjects were 60 EFL (male $=10$, female $=50$ ) students in the Department of English Language and Literature at a university in Turkmenistan. They were determined according to the convenience sampling strategy. All subjects have received an education in English for about three years at university, as well as taken specific English speaking courses in their department. They had not visited any English-speaking country, but had learned English in their country of origin. Their ages ranged from 18 to 26 years $(\mathrm{M}=20.90, \mathrm{SD}=1.88)$ and their speaking exam scores ranged from 36 to 98 out of $100(\mathrm{M}=74.57, \mathrm{SD}=14.58)$.

\subsection{Instruments}

As a data collection instrument, a metaphor elicitation form, in two sections, was used in the study. The form was decided in accordance with the literature [51, 52]. The first section included demographic questions about each learner's gender, age, experience of learning English and the last speaking exam score (out of 100), as well as two prompts: "Speaking English is like... because..." and "A good speaker of English is like... because..."

\subsection{Data Collection and Analysis}

The data were collected during the second semester of the 2014-15 academic year. The subjects were informed about voluntary participation, anonymity, writing a metaphor and the metaphor vehicle. The researcher also presented sample metaphors and clarification sentences. Then, the forms were given to the students, on which they each wrote only one metaphor and the reason behind the resemblance for each prompt. This process took about 15 minutes.

The data were transferred to a computer and subjected to descriptive and content analyses. Frequencies and means were calculated, while conceptual themes regarding each prompt were determined. Two experts from the educational research area worked together in order to determine valid metaphors. There were 47 metaphors and five categories for the first prompt and 26 metaphors and six categories for the second prompt in the course of joint working by the experts. During this process, labelling, sorting, deciding upon the unit of analysis, and categorization stages were followed, based on the study of Saban and colleagues [44]. In the data presentation, tables and pie charts were used, while students' excerpts were given as subject (S) 1, 2, 3, etc. in order to distinguish between the subjects.

\section{Findings}

The findings were presented in accordance with the two aspects in the prompts.

\subsection{Speaking English}

Fifty EFL learners generated 46 metaphors about speaking in English. Their metaphors were allocated according to five categories. Metaphors and categories are presented below: 
Table 1. Conceptual categorization of the metaphors about speaking English

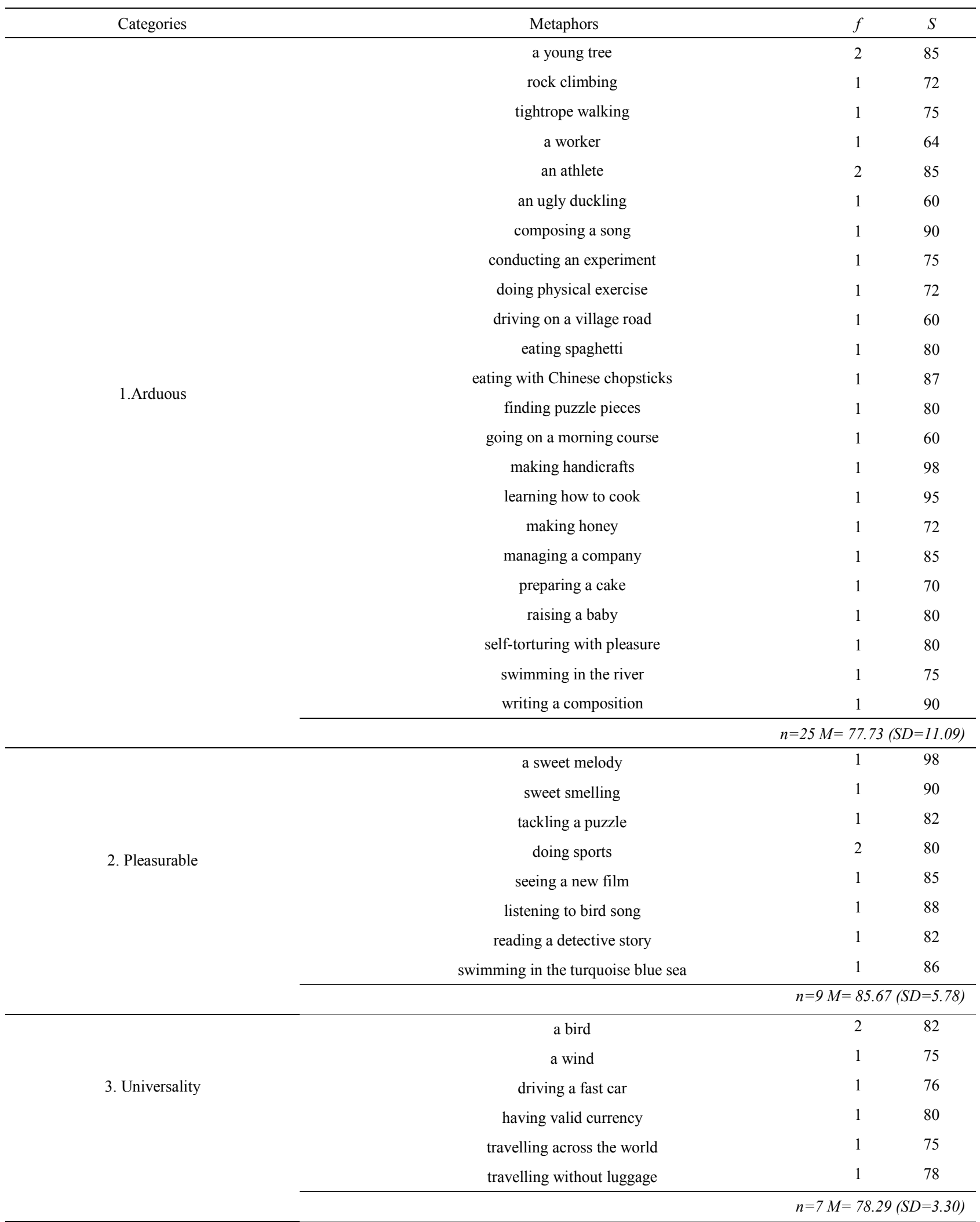


Table 1. Continued

\begin{tabular}{|c|c|c|c|}
\hline Categories & Metaphors & $\mathrm{f}$ & $\mathrm{S}$ \\
\hline \multirow{6}{*}{ 4. Privileged } & being a film star & 1 & 75 \\
\hline & being a princess & 1 & 78 \\
\hline & being a president & 1 & 72 \\
\hline & having a luxury car & 1 & 65 \\
\hline & wearing expensive jewellery & 1 & 68 \\
\hline & & \multicolumn{2}{|c|}{$n=5 M=71.60(S D=5.22$} \\
\hline \multirow{4}{*}{$\begin{array}{l}\text { 5. Anxiety- } \\
\text { provoking }\end{array}$} & burning in a fire & 1 & 50 \\
\hline & having a nightmare & 1 & 60 \\
\hline & lingering moment & 1 & 36 \\
\hline & watching a horror film & 1 & 60 \\
\hline
\end{tabular}

Notes: f: frequency; S: score; $\mathrm{n}$ : total group frequency; M: mean of the score. All values rounded to the nearest whole number.

As shown in the table, the learners' generated metaphors mostly related to the difficulty of the speaking skill and the pleasure associated with the skill. They also focused on the universal role of English in today's world and thought that speaking English makes people unique in society. Four students described speaking as an anxiety-provoking activity and said that they felt as though they are having a nightmare or burning in a fire when they try to speak English. In addition to these metaphors, the learners' exam scores from the speaking exam were given in the table. Mean scores indicate that achievement based on the exam score changed from the lowest to the highest respectively in relation to the following: anxiety-provoking, arduous, privileged, universality and pleasurable.

A pie chart was created for ease of understanding concerning the conceptual categories in terms of frequency.

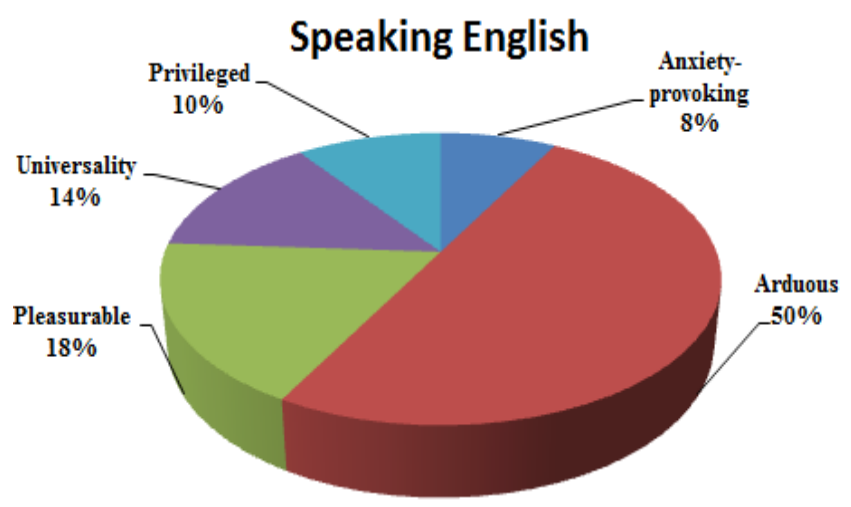

Chart 1. Speaking English

As illustrated in the chart, half of the learners $(50 \%)$ mostly described speaking as an arduous skill. They believed that speaking is a hard skill to acquire and that students should spend a considerable time speaking English in order to be more proficient. They also said that it was acceptable to make mistakes in this process and that the learner should be patient, study a lot and look to the future with hope.

About speaking English being arduous, S29 said:
"Speaking English is like a young tree because the tree needs water and sunshine in order to become a giant tree in the forest. Otherwise, it becomes thin and weak. If you do not practise enough and expand your vocabulary knowledge, your English will become like that tree." Another participant, S23, compared this category to an athlete: "An athlete needs a lot of training in order to win medals in championships and endure all the obstacles in this process."

The second category was about the joy and enjoyment related to the speaking skill for the learner. Associating speaking with doing sports, S16 said: “... when you do sports, you become relaxed and happy. This is the same as when you speak English."

The third category involved the universality of speaking English. Emphasizing the role of speaking in a globalizing world, S58 said: "Speaking English is like a bird because the bird can fly everywhere freely and there is no border for a bird. When you speak English, the world becomes so small for you; you can travel freely without fear."

The fourth category referred to the role of speaking in terms of becoming a privileged person. Five students associated it with money, fame and respect in society. On this issue, S54 said: "When there is a very luxurious car in traffic, everyone looks at it enviously."

The fifth category was concerned with the anxiety-provoking nature of speaking English. Stating that it is like burning in a fire, S9 said: “... it hurts you, and you want to run away from the fire. When I speak English, I feel like I am burning in the fire or so afraid that I can even forget my name, not just the vocabularies that I need to use."

\subsection{A Good Speaker of English}

Thirty-six learners generated 27 distinct metaphors for a good speaker of English. Their metaphors were allocated according to six categories. Details of the metaphors are presented below: 
Table 2. Conceptual categorization of the metaphors for a good speaker of English

\begin{tabular}{|c|c|c|c|}
\hline Categories & Metaphors & $f$ & $S$ \\
\hline \multirow{9}{*}{ 1. Fluent } & a horse & 1 & 76 \\
\hline & a fish in the water & 1 & 80 \\
\hline & a politician & 2 & 55 \\
\hline & a professional speaker & 1 & 85 \\
\hline & a reporter & 1 & 75 \\
\hline & a river & 3 & 84 \\
\hline & an Englishman & 1 & 60 \\
\hline & an angel & 1 & 50 \\
\hline & & \multicolumn{2}{|c|}{$n=11 M=71.63(S D=13.76)$} \\
\hline \multirow{6}{*}{ 2. Universality } & a bird & 3 & 79 \\
\hline & a BBC channel & 1 & 85 \\
\hline & a quick arrow & 1 & 87 \\
\hline & an ocean & 1 & 65 \\
\hline & an open sesame & 1 & 77 \\
\hline & & \multicolumn{2}{|c|}{$n=7 M=78.86(S D=7.10)$} \\
\hline \multirow{5}{*}{ 3. Wise } & a professor of English & 1 & 82 \\
\hline & a walking book & 1 & 93 \\
\hline & a wise man & 2 & 75 \\
\hline & a good singer & 1 & 95 \\
\hline & & \multicolumn{2}{|c|}{$n=5 M=82.80(S D=11.39)$} \\
\hline \multirow{3}{*}{ 4. Disarming } & a horse running on a beach & 1 & 75 \\
\hline & a sweet-voiced singer & 4 & 79 \\
\hline & & \multicolumn{2}{|c|}{$n=5 M=78.00(S D=17.54)$} \\
\hline \multirow{5}{*}{ 5. Privileged } & a millionaire & 2 & 80 \\
\hline & a noble horse breed & 1 & 73 \\
\hline & a president of the country & 1 & 85 \\
\hline & a queen & 1 & 73 \\
\hline & & \multicolumn{2}{|c|}{$n=4 M=80.75(S D=5.68)$} \\
\hline \multirow{5}{*}{ 6. Hardworking } & a successful film artist & 1 & 72 \\
\hline & an SUV & 1 & 85 \\
\hline & a victorious boxer & 1 & 90 \\
\hline & an ant & 1 & 73 \\
\hline & & \multicolumn{2}{|c|}{$n=4 M=80.00(S D=8.91)$} \\
\hline
\end{tabular}

Notes: f: frequency; S: score; $\mathrm{n}$ : total group frequency; M: mean of the score. All values rounded to the nearest whole number.

The table shows that the learners use many words, in the context of six features, to describe a good speaker of English. All the metaphors have positive meanings and present some characteristics of a good speaker. Unlike the table about speaking English, the learners' exam scores had little significance, with all categories having similar means.

As before, a pie chart was created for ease of understanding concerning the conceptual categories in terms of frequency.

According to the chart, a good speaker of English is a composite of someone who is fluent at speaking the language and an international, wise, privileged and hardworking person.

Many of the learners (31\%) perceived a good speaker to be a fluent speaker, making associations with words such as a flooding river and a politician. Focusing on fluency, S40 said: "A good speaker of English is like a river because the river flows quickly and it has clean water. Then a good speaker is someone who speaks very fast with a clear pronunciation." Another learner, S8, explained the association with politicians: “... because politicians can speak so fast and they can choose from attractive vocabularies within seconds."

\section{A Good Speaker of English}

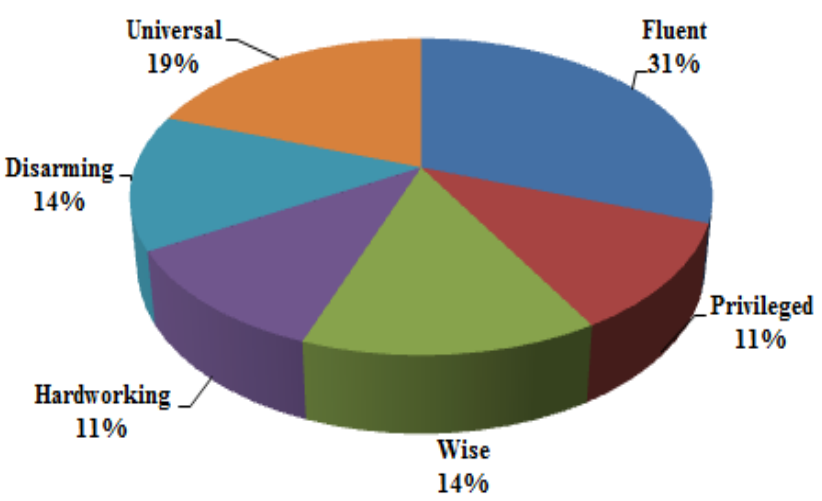

Chart 2. A Good Speaker of English

According to the chart, the second category concerned universality. Similar to speaking English, some of the learners focused on the universal nature of knowing a 
language and perceived English to be an international language. They associated a good speaker with a bird, a global TV channel etc. S44 said: "A good speaker of English is like a bird because the bird does not need a passport and can freely fly everywhere. If you are a good speaker, you can use your speaking skill everywhere you go."

The third category was concerned with being wise. The learners highlighted the importance of English to increasing knowledge and also having knowledge of the language itself. They described a good speaker as someone rich in general culture who knows a lot about the language. According to S2: "Because s/he reads a lot and knows a lot, s/he could also easily answer all your questions."

The fourth category referred to being disarming. The learners generated positive metaphors in terms of this category. They said that a good speaker mesmerizes listeners and makes them fully listen. In addition, one student compared a good speaker to a beautiful horse running on beach so happily that you cannot take yourself away from watching this scene. On this matter, S35 said: “... you can listen to a sweet-voiced singer many times without any boredom.”

The fifth category was concerned with being privileged. The learners emphasized the positive attributes of speaking English, saying that, if someone speaks well, they are admired within society. For S57: "A good speaker of English is like a president of a country because you feel like an important person in the world."

The sixth category referred to being hardworking. The learners perceived a good speaker as someone who works hard and spends a lot of practising. Explaining why they used the metaphor of an ant, S34 said: “... because an ant works 24/7."

\section{Discussion and Conclusion}

This study revealed EFL learners' metaphoric images for the speaking skill and for a good speaker of English. Consistent with the literature $[6,13]$, most of the learners found speaking was an extremely difficult and arduous task. They associated the speaking skill with activities, which are hard and require much time and effort to master. They also focused on the feelings of pleasure and enjoyment that speaking English gives them. They also associated speaking English with the role of English as an international language. They said that, when someone speaks English, they can easily travel across the world without any difficulty. Some of the learners also emphasized the role of speaking English in the context of a career, as well as suggesting that speaking English can make someone appear as a privileged person whom everyone envies. However, few students used negative metaphors to define speaking. They said that speaking English is an anxiety-provoking activity for them. They were uneasy about speaking English and described it as a nightmare or a lingering moment. According to the achievement scores, the latter learners are the ones with the lowest levels of achievement. Although establishing this was not the purpose of the current study, it is important to note here that learners' beliefs regarding the speaking of English seem to be associated with their level of achievement in English courses. As stated by Wenden [53], learners with different proficiency levels will have different beliefs regarding learning, as they grasp the relevant knowledge with different levels of success. It was also discovered that negative beliefs are associated with a high level of anxiety and a low level of achievement [54, 55]. This may discourage learners and encourage them to make less effort [35].

In language learning settings, success is often equated with carrying out a conversation in the target language, with oral fluency accepted as a measure of language assessment [56]. Similarly, most of the EFL learners depicted an excellent speaker of English as someone who is fluent in English; in other words, someone who speaks English without hesitation. Further, they compared the speaker to a fast-flowing river or a politician who is good at making use of attractive vocabularies in order to talk effortlessly. These findings may relate to the claim that the primary goal of many language learners is to speak English fluently [5, 57]. In addition, this category has the lowest achievement mean and the highest number of low achievers in tests compared to other categories. This result might be concerned with learners' actual needs [33]. Similar to the metaphor for speaking English, the learners also focused on the positive aspects of speaking English. They said that a good speaker of English is someone who has lots of knowledge about any issue, attracts you with their voice, has some privileges in society and works very hard for success.

In conclusion, the findings indicated that the speaking skill is a hard skill to master, while a good speaker of English is someone fluent in English. In other words, learners have mainly positive connotations in their mind. As stated by Riley [27], beliefs shape attitudes, motivation and learning strategies. Accordingly, both EFL learners and teachers in input-poor environments should share the responsibility for creating positive beliefs regarding speaking. Based on the findings, it can be suggested that learners should be aware of their own ideas, understand the origins of these ideas and focus on successfully addressing their weak points. Moreover, they should spend as much time as possible in order to become more fluency and observe the characteristics of good speakers of English. Teachers should consider the differences in learners' beliefs and satisfy students' needs by addressing their motives behind learning to speak English. In turn, teachers should adapt their teaching practices so that each student can easily find their own relevance and take part in the learning process.

Lastly, this qualitative study is not without weaknesses. It involved a very limited number of subjects for multiple 
comparisons, depending on demographic details, such as the experience of learning English and time spent abroad to learn English or live in an English-speaking country. As stated in Amuzie and Winke [58], spending time abroad and having as much experience as possible in learning a foreign language can positively impact on learners' beliefs. Therefore, research focusing on group differences, such as experience, and time spent abroad, might be an interesting angle from which to further examine the phenomenon.

\section{Acknowledgements}

I would like to thank the anonymous reviewers of this manuscript and the journal editor for their help to improve the quality of the article.

\section{REFERENCES}

[1] Shuell, T.J., Teaching and learning as problem solving. Theory into Practice, 1990, 29(2): p. 102-108.

[2] Bygate, M., Speaking, 1987. Oxford: Oxford University Press.

[3] Crystal, D., English as a global language, 1997. Cambridge \& New York: Cambridge University Press.

[4] Dincer, A. and Yesilyurt, S., Pre-service English teachers' beliefs on speaking skill based on motivational orientations. English Language Teaching, 2013. 6(7): p. 88-95.

[5] Nazara, S., Students' perception on EFL speaking skill development. Journal of English Teaching, 2011. 1(1): p. $28-42$.

[6] Hinkel, E., (Ed.) Handbook of research in second language teaching and learning, 2005. London: Lawrence Erlbaum Associates Publishers.

[7] Penny, U., A course in Language Teaching: Practice and theory, 1996. Cambridge: Cambridge University Press.

[8] Lakoff, G. and M. Johnson, Metaphors we live by, 1980. Chicago: The University of Chicago Press.

[9] Jung, U.O.H., Retrospective review article: Speaking-The second skill. System, 1995. 23(1): p. 107-112.

[10] Firth, A., The discursive accomplishment of normality: On 'lingua franca' English and conversation analysis. Journal of Pragmatics, 1996. 26(2): p. 237-259.

[11] Gan, Z., Understanding L2 speaking problems: Implications for ESL Curriculum development in a teacher training institution in Hong Kong. Australian Journal of Teacher Education, 2012. 37(1): p. 43-59.

[12] Kang, D.-M., The effects of study-abroad experiences on EFL learners' willingness to communicate, speaking abilities, and participation in classroom interaction. System, 2014. 42: p. 319-332.

[13] Pawlak, M., E. Waniek-Klimczak, and J. Majer, Speaking and instructed foreign language acquisition. 2011. UK: Multilingual Matters.

[14] Li, D., " It's Always More Difficult Than You Plan and Imagine": Teachers' Perceived Difficulties in Introducing the Communicative Approach in South Korea. TESOL Quarterly, 1998. 32(4): p. 677-703.

[15] Shumin, K., Factors to consider: Developing adult EFL students' speaking abilities. English Teaching Forum, 1997. 35(3): p. 8.

[16] Kouraogo, P., Language learning strategies in input-poor environments. System, 1993. 21(2): p. 165-173.

[17] Liu, N.-F. and W. Littlewood, Why do many students appear reluctant to participate in classroom learning discourse? System, 1997. 25(3): p. 371-384.

[18] Horwitz, E.K., M.B. Horwitz, and J. Cope, Foreign language classroom anxiety. The Modern Language Journal, 1986. 70(2): p. 125-132.

[19] Liu, M. and J. Jackson, An exploration of Chinese EFL learners' unwillingness to communicate and foreign language anxiety. The Modern Language Journal, 2008. 92(1): p. $71-86$.

[20] Young, D.J., An investigation of students' perspectives on anxiety and speaking. Foreign Language Annals, 1990. 23(6): p. 539-553.

[21] Kim, D. and D. Margolis, Korean student exposure to English listening and speaking: Instruction, multimedia, travel experience and motivation. The Korea TESOL Journal, 2000. 3(1): p. 29-54.

[22] Songsiri, M., An action research study of promoting students' confidence in speaking English (Unpublished $\mathrm{Ph}$. D. dissertation). 2007, Victoria University, Australia.

[23] Ushioda, E., Redefining motivation from the L2 learner's point of view. Teanga, 1993. 13: p. 1-12.

[24] Horwitz, E.K., The beliefs about language learning of beginning university foreign language students. The Modern Language Journal, 1988. 72(3): p. 283-294.

[25] Breen, M.P., (Ed.) Learner contributions to language learning: New directions in research. 2001: Harlow, Essex: Pearson Education Limited.

[26] Ellis, N.C., The dynamics of second language emergence: Cycles of language use, language change, and language acquisition. The Modern Language Journal, 2008. 92(2): p. 232-249.

[27] Riley, P. BATS' and 'BALLS': Beliefs about talk and beliefs about language learning. Mélanges CRAPEL, 1996. 23: p.125-153.

[28] Farjami, H., EFL learners' metaphors and images about foreign language learning. Studies in Second Language Learning and Teaching, 2012. 2(1): p. 93-109.

[29] Horwitz, E.K., Using student beliefs about language learning and teaching in the foreign language methods course. Foreign Language Annals, 1985. 18(4): p. 333-340.

[30] Mantle - Bromley, C., Positive attitudes and realistic beliefs: Links to proficiency. The Modern Language Journal, 1995. 79(3): p. 372-386. 
[31] Vibulphol, J., Beliefs about language learning and teaching approaches of pre-service EFL teachers in Thailand. (Unpublished Ph. D. dissertation). 2004, Oklahoma State University, USA.

[32] Williams, M., et al., Learners' perceptions of their successes and failures in foreign language learning. Language Learning Journal, 2004. 30(1): p. 19-29.

[33] Peacock, M., Beliefs about language learning and their relationship to proficiency. International Journal of Applied Linguistics, 1999. 9(2): p. 247-263.

[34] Yang, J.-S. and T.-Y. Kim, Sociocultural analysis of second language learner beliefs: A qualitative case study of two study-abroad ESL learners. System, 2011. 39(3): p. 325-334.

[35] Horwitz, E.K., Surveying student beliefs about language learning in Learner Strategies in Language Learning, A. Wenden and R. Rubin, Editors. 1987. London: Prentice Hall International. p. 121-130.

[36] Wan, W., G.D. Low, and M. Li, From students' and teachers' perspectives: Metaphor analysis of beliefs about EFL teachers' roles. System, 2011.39(3): p. 403-415.

[37] Kaypak, E. and D. Ortaçtepe, Language learner beliefs and study abroad: A study on English as a lingua franca (ELF). System, 2014. 42: p. 355-367.

[38] Yan, J.X. and E.K. Horwitz, Learners' perceptions of how anxiety interacts with personal and instructional factors to influence their achievement in English: A qualitative analysis of EFL learners in China. Language Learning, 2008. 58(1): p. 151-183.

[39] White, C., Beliefs and good language learners in Lessons from Good Language Learners, C. Griffiths, Editor. 2008, Cambridge: Cambridge University Press. p. 121-130.

[40] Leary, D.E., Psyche's muse: The role of metaphor in the history of psychology in Metaphors in the history of psychology, David E. Leary, Editor. 1990, Cambridge: Cambridge University Press. p. 1-78.

[41] McGrath, I., Using insights from teachers' metaphors. Journal of Education for Teaching, 2006. 32(3): p. 303-317.

[42] Koc, M., Student teachers' conceptions of technology: A metaphor analysis. Computers \& Education, 2013. 68: p. 1-8.

[43] Martinez, M.a.A., N.s. Sauleda, and G.L. Huber, Metaphors as blueprints of thinking about teaching and learning. Teaching and Teacher Education, 2001. 17(8): p. 965-977.

[44] Saban, A., B.N. Kocbeker, and A. Saban, Prospective teachers' conceptions of teaching and learning revealed through metaphor analysis. Learning and Instruction, 2007. 17(2): p. 123-139.

[45] Jin, L., et al., Studying the motivations of Chinese young EFL learners through metaphor analysis. ELT Journal, 2014. 68(3): p. $286-298$

[46] Yeşilyurt, S., An Attempt for the Exploration of Academicians' Experiences of the Standard Foreign Language Tests Held in Turkey through Metaphors. International Journal of Higher Education, 2016. 5(2): p. p263.

[47] Seferoğlu, G., S. Korkmazgil, and Z. Ölçü, Gaining insights into teachers' ways of thinking via metaphors. Educational Studies, 2009. 35(3): p. 323-335.

[48] Borg, S., Teacher cognition and language education: Research and practice. 2015: Bloomsbury Publishing.

[49] Chen, Z. and C. Goh, Teaching oral English in higher education: Challenges to EFL teachers. Teaching in Higher Education, 2011. 16(3): p. 333-345.

[50] Creswell, J., Qualitative inquiry and research method: Choosing among five approaches. 2007, Thousand Oaks, CA: Sage.

[51] Schmitt, R., Systematic metaphor analysis as a method of qualitative research. The qualitative Report, 2005. 10(2): p. 358-394.

[52] Saban, A., Functions of metaphor in teaching and teacher education: A review essay. Teaching Education, 2006. 17(4): p. 299-315.

[53] Wenden, A.L., Metacognitive knowledge and language learning1. Applied linguistics, 1998. 19(4): p. 515-537.

[54] Mori, Y., Epistemological beliefs and language learning beliefs: What do language learners believe about their learning? Language Learning, 1999. 49(3): p. 377-415.

[55] Horwitz, E.K., Cultural and situational influences on foreign language learners' beliefs about language learning: A review of BALLI studies. System, 1999. 27(4): p. 557-576.

[56] Bosker, H.R., et al., What makes speech sound fluent? The contributions of pauses, speed and repairs. Language Testing, 2012: p. 1-17.

[57] Kawai, Y., Speaking and good language learners in Lessons from Good Language Learners, C. Griffiths, Editor. 2008, Cambridge: Cambridge University Press. p. 218-230.

[58] Amuzie, G.L. and P. Winke, Changes in language learning beliefs as a result of study abroad. System, 2009. 37(3): p. 366-379. 